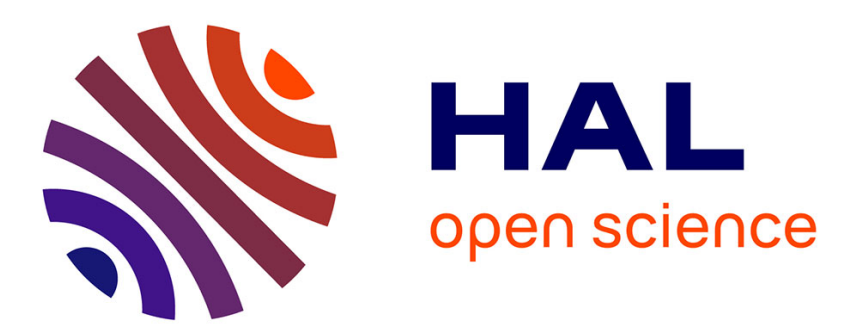

\title{
Thyroid hormone receptor expression during metamorphosis of Atlantic halibut ()
}

Malyka Galay-Burgos, Deborah M. Power, Lynda Llewellyn, Glen E. Sweeney

\section{To cite this version:}

Malyka Galay-Burgos, Deborah M. Power, Lynda Llewellyn, Glen E. Sweeney. Thyroid hormone receptor expression during metamorphosis of Atlantic halibut (). Molecular and Cellular Endocrinology, 2007, 281 (1-2), pp.56. 10.1016/j.mce.2007.10.009 . hal-00531956

\section{HAL Id: hal-00531956 https://hal.science/hal-00531956}

Submitted on 4 Nov 2010

HAL is a multi-disciplinary open access archive for the deposit and dissemination of scientific research documents, whether they are published or not. The documents may come from teaching and research institutions in France or abroad, or from public or private research centers.
L'archive ouverte pluridisciplinaire HAL, est destinée au dépôt et à la diffusion de documents scientifiques de niveau recherche, publiés ou non, émanant des établissements d'enseignement et de recherche français ou étrangers, des laboratoires publics ou privés. 


\section{Accepted Manuscript}

Title: Thyroid hormone receptor expression during metamorphosis of Atlantic halibut (Hippoglossus

hippoglossus)

Authors: Malyka Galay-Burgos, Deborah M. Power, Lynda Llewellyn, Glen E. Sweeney

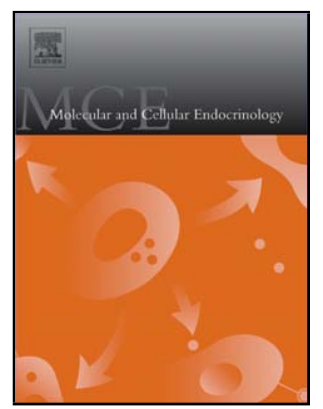

PII: S0303-7207(07)00388-7

DOI: doi:10.1016/j.mce.2007.10.009

Reference: MCE 6727

To appear in: $\quad$ Molecular and Cellular Endocrinology

Received date: $\quad 9-5-2007$

Revised date: 2-10-2007

Accepted date: $\quad$ 19-10-2007

Please cite this article as: Galay-Burgos, M., Power, D.M., Llewellyn, L., Sweeney, G.E., Thyroid hormone receptor expression during metamorphosis of Atlantic halibut (Hippoglossus hippoglossus), Molecular and Cellular Endocrinology (2007), doi:10.1016/j.mce.2007.10.009

This is a PDF file of an unedited manuscript that has been accepted for publication. As a service to our customers we are providing this early version of the manuscript. The manuscript will undergo copyediting, typesetting, and review of the resulting proof before it is published in its final form. Please note that during the production process errors may be discovered which could affect the content, and all legal disclaimers that apply to the journal pertain. 
Thyroid hormone receptor expression during metamorphosis of Atlantic halibut (Hippoglossus hippoglossus)

Malyka Galay-Burgos ${ }^{1}$, Deborah M. Power ${ }^{2}$, Lynda Llewellyn ${ }^{1}$, and Glen E. Sweeney ${ }^{1}$.

${ }^{1}$ School of Biosciences, University of Wales, Museum Avenue CF10 3US Cardiff, UK.

${ }^{2}$ Comparative Molecular Endocrinology Group, Marine Science Centre (CCMAR), Universidade do Algarve, 8005-139 Faro, Portugal.

Corresponding author: Glen Sweeney

\begin{abstract}
Flatfish such as the Atlantic halibut (Hippoglossus hippoglossus) undergo a dramatic metamorphosis that transforms the pelagic, symmetric larva into a benthic, cranially asymmetric juvenile. In common with amphibian metamorphosis, flatfish metamorphosis is under endocrine control with thyroid hormones being particularly important. In this report we confirm that tri-iodothyronine $\left(\mathrm{T}_{3}\right)$ levels peak at metamorphic climax during halibut metamorphosis. Moreover we have isolated cDNA clones of TR $\alpha$ and TR $\beta$ genes and confirmed the presence in halibut of two TR $\alpha$ isoforms (representing the products of distinct genes) and two TR $\beta$ isoforms (generated from a single gene by alternative splicing). Real time PCR was used to assess expression of these genes during metamorphosis. TR $\beta$ shows the most dramatic expression profile, with a peak occurring during metamorphic climax.
\end{abstract}




\section{Introduction}

The link between thyroid hormones (TH) and the onset and progression of amphibian metamorphosis (reviewed by Brown and Cai, 2007; Tata, 2006; Sachs et al., 2000) has been known for almost a century (Gudernatsch, 1912). More recent research, notably some incisive and elegant transgenic animal studies, has emphasised the importance of thyroid hormone receptors (Buchholz et al., 2006; Buchholz et al., 2004; Schreiber et al., 2001) and iodothyronine deiodinases in the process (Brown, 2005; Cai and Brown, 2004). However, amphibia are not the only vertebrates that undergo metamorphosis. The development of fish involves a metamorphosis from larval to juvenile form that is manifest most dramatically in flatfish (pleuronectiformes) such as sole, halibut and flounder. In these species, the pelagic larva undergoes extensive remodelling which leads to a loss of external bilateral symmetry and generates a benthic juvenile with both eyes on the same, pigmented, side of the body. These morphological changes are scarcely less profound than those of amphibian metamorphosis but are clearly distinct from them. On the other hand, some of the biochemical and physiological changes that accompany metamorphosis, such as switching of globin (Wakahara and Yamaguchi, 2001; Miwa and Inui, 1991) and keratin (Campinho et al., 2007a) types and the production of new isoforms of muscle proteins (Yamano et al., 1991a; Campinho et al., 2007b) are similar in flatfish and amphibia. Still more significantly, there is strong evidence that thyroid hormones regulate metamorphosis in flatfish in much the same manner as in amphibia. Hence, metamorphosis in Japanese flounder (Paralichthys olivaceus) and Atlantic halibut (Hippoglossus hippoglossus) is induced precociously by TH treatment and Japanese 
flounder metamorphosis is delayed or abolished following exposure to agents that inhibit TH synthesis (DeJesus et al., 1993; Solbakken et al., 1999).

THs exert their genomic effects by binding to thyroid hormone receptors (TRs). THs also have non-genomic effects (Davis and Davis, 1986), some of which are also mediated via the TRs mentioned above (Hiroi et al., 2006). However the genomic actions alone of thyroid hormones may be sufficient for metamorphosis in amphibia (Buchholz et al., 2004). TRs are members of the nuclear receptor superfamily, and act as hormoneregulated transcription factors (reviewed in Zhang and Lazar, 2000; Oetting and Yen, 2007). They usually activate the transcription of target genes when complexed with hormone but act as repressors in the absence of ligand, although some genes are repressed rather than induced by THs. There are two principal isoforms of TRs in vertebrates, designated TR $\alpha$ and TR $\beta$, which are the products of distinct genes. The mammalian TR $\alpha$ and $\operatorname{TR} \beta$ genes produce a variety of additional receptor isoforms via alternative splicing and the use of alternative transcription start sites, (Lazar, 1993; Flamant and Samurat, 2003). The functions of TR $\alpha$ and TR $\beta$ have been extensively investigated in transgenic mice and it is clear that, in vivo, they have both common and isoform-specific roles (reviewed by Cheng, 2005; Flamant and Samurat, 2003). For example, TR $\beta$ isoforms are more important than those of TR $\alpha$ in the inner ear (Forrest et al., 1996a), liver, and in TH homeostasis (Forrest et al., 1996b), whereas TR $\alpha$ isoforms play a more significant role in the heart (Mai et al., 2004) and GI tract and also in temperature regulation. These differences in function in vivo between TR $\alpha$ and TR $\beta$ may arise as a result of slight biochemical differences between the isoforms (for example, see 
Guissouma et al., 2002). However, microarray analysis of TH-induced gene expression in liver from $\mathrm{TR} \alpha$ and $\mathrm{TR} \beta$ deficient mice indicates that the two isoforms regulate almost the same set of genes (Yen et al., 2003). Hence, some or all of the functional differences between the receptor types may simply be a reflection of differences in their expression profiles.

The teleosts also possess TR $\alpha$ and $\operatorname{TR} \beta$ but, in contrast to mammals, Japanese flounder, conger eel (Conger myriaster) and Atlantic salmon (Salmo salar) have two distinct TR $\alpha$ genes (Yamano et al., 1994; Marchand et al., 2001; Jones et al., 2002; Kawakami et al., 2003a). Conger eel also has two TR $\beta$ genes, and whilst only a single TR $\beta$ gene has been found in other teleosts examined to date, further TR $\beta$ isoforms have been described that result from alternative splicing (Yamano and Inui, 1995; Marchand et al., 2001; Kawakami et al., 2003b). We have previously described (Llewellyn et al., 1999) a full length TR $\alpha$ (henceforth designated as TR $\alpha \mathrm{A}$ ) from a commercially important flatfish species, the Atlantic halibut (Hippoglossus hippoglossus). Here we describe partial clones of a second TR $\alpha$ gene (designated TR $\alpha \mathrm{B}$ ) and the TR $\beta$ gene from this key species. Real time PCR was subsequently used to assess the expression of all three TR genes during metamorphosis and has been related to changes in whole body $\mathrm{TH}$ concentration.

\section{Materials and Methods.}

\subsection{Sampling}


Halibut larvae were cultured using standard commercial procedures. Broodstock fish were stripped for eggs and milt, and eggs were fertilised in vitro and then placed in open system egg incubators at $5.0-5.5^{\circ} \mathrm{C}$ for 14 days and then transferred to open system silos. For the next 45-50 days the larvae were kept in the dark at a temperature of $5-6^{\circ} \mathrm{C}$, after which they were transferred to the first feeding tanks at $11^{\circ} \mathrm{C}$ and fed live feed (Artemia) for approximately 60 days. After metamorphosis the bottom dwelling juveniles were transferred to weaning tanks and gradually weaned for 10 days on dry feeds. Samples were taken from a standard commercial production cycle (Fiskeldi Eyjafjarðar Ltd, Iceland) at regular intervals and larvae were staged according to the criteria of Sæle et al (2004). Larvae were stored at $-20^{\circ} \mathrm{C}$ in RNAlater prior to RNA extraction using Trireagent.

\subsection{TH extraction and Radioimmunoassay}

The $T_{4}$ and $T_{3}$ content of halibut larvae was assessed by specific radioimmunoassay (RIA). Individual larvae of stages $5(\mathrm{n}=10), 6(\mathrm{n}=10), 7(\mathrm{n}=8), 8(\mathrm{n}=7), 9(\mathrm{n}=6)$ and $10(n=6)$ were extracted in methanol, re-extracted in $50 \mu 1$ methanol, $200 \mu$ l chloroform and $100 \mu \mathrm{l}$ barbital buffer, and centrifuged $\left(3,000 \mathrm{rpm}\right.$ for $30 \mathrm{~min}$ at $\left.4^{\circ} \mathrm{C}\right)$. Then, the upper phase was removed, lyophilised, reconstituted in assay buffer, heat treated $\left(65^{\circ} \mathrm{C}, 2 \mathrm{~h}\right)$ and assayed. Assays for both $T_{3}$ and $T_{4}$ were highly specific and reproducible and were performed under equilibrium conditions using anti- $\mathrm{T}_{3}$ and anti- $\mathrm{T}_{4}$ sera (Sigma-Aldrich) as previously described (Einarsdottir et al., 2006). Statistically significant differences in the concentration of $T_{4}$ or $T_{3}$ detected for different stages were compared by ANOVA on log 
transformed data, followed by All Pairwise Multiple Comparison Procedures (HolmSidak method). Results were considered to be significantly different at $\mathrm{p}<0.05$.

\subsection{Cloning of TRs}

PCR using degenerate primers was used in order to isolate partial clones of halibut TRs. A multispecies alignment was performed using TR sequences from a variety of vertebrate species and degenerate PCR primers were designed that corresponded to particularly well conserved motifs. One primer pair (forward primer:

AATGYCGCTTCAARAARTGYAT, reverse primer: GTAAACTGRCTRAAGGCYTC) was used in RT-PCR reactions in which the substrate was RNA isolated from metamorphosing halibut larvae. The PCR products generated were gel purified, subcloned into pGEM-T (Promega, UK) and sequenced.

\subsection{Sequence analysis}

Complete or partial nucleotide sequences of TRs from Fugu rubripes were obtained by BlastN searching of the Fugu genome (http://fugu.biology.qmul.ac.uk) with the halibut TR $\alpha \mathrm{A}, \mathrm{TR} \alpha \mathrm{B}$ and TR $\beta$ sequences. The intron-exon structure of the Fugu TR $\beta$ gene was deduced using Spidey (http://www.ncbi.nlm.nih.gov/spidey/) to identify sequences within the individual Fugu scaffold M001021 that showed strong similarity with known teleost TR mRNAs, followed by manual comparison of the putative splice sites in the Fugu sequence with the consensus sequences for vertebrate $5^{\prime}$ and $3^{\prime}$ splice junctions.

2.5 Real-time RT-PCR analysis of gene expression 
RNA was prepared from five replicate individuals from stages 5 (larvae prior to onset on metamorphosis) through to stage 10 (fully metamorphosed juveniles) using Tri-reagent (Sigma-Aldrich) and subsequently treated with DNAse (Ambion) according to the manufacturer's instructions. cDNA was prepared from $0.5 \mu \mathrm{g}$ aliquots of each RNA using random hexamer primers and superscript II reverse transcriptase (Invitrogen).

Expression of the genes encoding TR $\alpha 1, T R \alpha 2$ and TR $\beta$ was quantified using real-time RT-PCR using fluorogenic $5^{\prime}$ nuclease assays performed on an ABI PRISM ${ }^{\circledR} 7700$ Sequence Detection System (Perkin-Elmer Biosystems, UK). The sequences of the primers and TaqMan probes used in each assay were as follows: TR $\alpha \mathrm{A}$, primers TTGTTGGACATTGGCTCCATT and CCGCCTCATTGTCCTGTGAT, probe TGCCTCAGTACCGTCCAGCGG; TR $\alpha$ B, primers TGCGTCGCTCCCTGTTCT and TTGGTGCTGGACGACTCAAA, probe TCGATCAGACGCCGCTTCGCT; TR $\beta$, primers TGGTGACTGACGCCCATATG and CAGGAATTTCCGCTTCTGCTT, probe CCACGAATGCCCAGGGCAACC. RT-PCR assays, using 5\% of the cDNA generated in the reactions described above, were normalised with respect to expression of $18 \mathrm{~s}$ rRNA, for which the primers were GCATGCCGGAGTCTCGTT and TGCATGGCCGTTCTTAGTTG, and the probe sequence was CCACGAATGCCCAGGGCAACC. Isoform specificity of the probes and primers was confirmed by experiments in which each primer/probe combination was tested for its ability to amplify DNA from the plasmid clones of TR $\alpha \mathrm{A}, \mathrm{TR} \alpha \mathrm{B}$ and TR $\beta$. Each individual sample was analysed in triplicate. One way analysis of variance (ANOVA) was used to assess differences between means, after testing for homogeneity of group 
variances and normality of residuals. Tukey post hoc tests subsequently identified which stages were significantly different $(\mathrm{p}<0.05)$ from the others for each of the genes analysed.

\subsection{PCR-analysis of TR- $\beta$ alternative splicing products}

To check for the presence of splice variants involving the hinge region of halibut TR $\beta$, two primers were designed (AGCTGCAGAAGACGGTGTG and

CAGGTGTATTTGCCATGGAC) that spanned the potential alternatively spliced exons. These were used in PCR reactions in which the substrate was cDNA from a variety of adult tissues and whole larvae prepared as described above. PCR reactions were performed for 40 cycles.

\section{Results}

\subsection{Cloning of thyroid hormone receptors}

We have previously described a full length halibut cDNA clone representing a thyroid receptor $\alpha$ gene (Llewellyn et al., 1999). However, three different thyroid hormone receptor genes, TR $\alpha \mathrm{A}, \mathrm{TR} \alpha \mathrm{B}$ and $\mathrm{TR} \beta$ have previously been identified in Japanese flounder (Yamano et al., 1994; Yamano and Inui, 1995), conger eel (Kawakami et al., 2003a) and Atlantic salmon (Marchand et al., 2001; Jones et al., 2002). Moreover, our analyses of the publicly available sequence from the Fugu genome indicate the presence of two distinct TR $\alpha$ genes and a single TR $\beta$ gene in this species also (data not shown). 
The Atlantic halibut TR gene that we had previously isolated shared highest similarity with Japanese flounder TR $\alpha$ A.

RT-PCR with degenerate primers was used to obtain partial clones of other halibut TRs. The degenerate primers utilised flank the sequences that encode the hinge (D) region and part of the ligand binding (E) domain of TR. When used with cDNA prepared from metamorphosing halibut, the primers amplified fragments of $358 \mathrm{bp}$ and $331 \mathrm{bp}$. Both fragments were subcloned and sequenced, and used in blast searches and phylogenetic analyses. The 358bp PCR fragment was unambiguously identified as TR $\beta$. The $331 \mathrm{bp}$ fragment was found to encode a TR $\alpha$ different from the one previously isolated (Llewellyn et al., 1999) and showed highest similarity to Japanese flounder TR $\alpha$ B, suggesting the amplified $331 \mathrm{bp}$ fragment represents halibut $\mathrm{TR} \alpha \mathrm{B}$. The larger size of the TR $\beta$ PCR product (358bp) is the result of a $27 \mathrm{bp}$ insertion present in most teleost TR $\beta$ genes described to date (see below), but absent in all TR $\alpha$ s, all tetrapod TR $\beta s$, and TRs from dogfish and lamprey (GenBank accession numbers ABC49722, ABC49723, AAO53268, AAO532689). The amino acid sequences encoded by the cloned halibut $\mathrm{TR} \alpha \mathrm{B}$ and $\mathrm{TR} \beta$, together with the corresponding region of halibut $\mathrm{TR} \alpha \mathrm{A}$, are shown in Fig 1.

\subsection{Expression of TRs during metamorphosis}

Real time PCR was used to quantify expression of halibut TR $\alpha \mathrm{A}, \mathrm{TR} \alpha \mathrm{B}$ and TR $\beta$ during metamorphosis. The larvae used were staged as described previously (Sæle et al., 2004) and expression levels were normalised with respect to the expression of $18 \mathrm{~s}$ rRNA. The 
results of these analyses are presented in Fig. 2. TR $\alpha$ A is expressed in all stages with an apparent peak at stage 9 (metamorphic climax). However, there was considerable variability between individual larvae at this stage and this peak was not statistically significant. TR $\alpha \mathrm{B}$ is expressed throughout metamorphosis with a peak at stage 7 and a marked, statistically significant decline $(\mathrm{p}<0.05)$ in expression on the completion of metamorphosis at stage $10 . \operatorname{TR} \beta$ shows the most dramatic expression profile with a clear, statistically significant peak $(\mathrm{p}<0.05)$ during stage 9 .

\subsection{Atlantic halibut whole body TH during metamorphosis}

$\mathrm{T}_{3}$ and $\mathrm{T}_{4}$ contents were determined in larvae from stage 5-10 and the results are shown in Fig. 2. $\mathrm{T}_{4}$ levels are low and relatively constant from stage 5 to stage 8 larvae and low levels of $\mathrm{T}_{3}$ are also detected and decline significantly $(\mathrm{p}<0.05)$ from stage 5 to stage 8 larvae. Subsequently, $T_{3}$ levels peak dramatically at metamorphic climax (stage 9) and are still significantly $(\mathrm{p}<0.05)$ elevated in post-metamorphic (stage 10) animals. Prior to stage $9 \mathrm{~T}_{4}$ is considerably more abundant that $\mathrm{T}_{3}$, but this relationship is inverted in stages 9 and 10 .

\subsection{TR $\beta$ splice variants}

In teleosts, TR $\beta$ splice variants have been identified that involve the linker region of TR $\beta$ (Yamano and Inui, 1995; Marchand et al., 2001; Kawakami et al., 2003b), which includes the 27 nucleotide fish TR $\beta$-specific insert described above (Fig. 1). To determine whether any such splice variants arise during Atlantic halibut metamorphosis, RT-PCR was performed using RNA from all larval stages and a variety of adult tissues with 
primers that flank the TR $\beta$ linker region. Each sample generated two discrete PCR products (Fig. 3a), the smaller of which was of the size predicted from the sequence of the TR $\beta$ clone (including the $27 \mathrm{bp}$ insert) while the larger fragment contained an additional $60 \mathrm{bp}$. Sequence analysis of the two fragments revealed that the smaller fragment corresponded exactly to that of the Atlantic halibut TR $\beta$ sequence described above, and that the larger fragment was identical to the smaller with the exception of a 60 bp insert directly upstream of the $27 \mathrm{bp}$ fish TR $\beta$-specific insert (see Fig. 3c). This resembles the situation in Japanese flounder where two similar TR $\beta$ splice variants occur. We therefore follow the flounder nomenclature in designating the smaller variant TR $\beta A$ and the larger TRßB.

The real-time PCR analysis presented in Fig. 2 utilised TR $\beta$ primers that recognise sequences common to both splice variants. It should be noted that the PCRs shown in Fig. 3a are not quantitative and do not allow comparison of expression levels between samples but do allow estimation of the ratio of the two splice variants which, as in a competitive PCR, should be independent of cycle number. Therefore, to determine whether there was a change in the ratio of the TR $\beta$ isoforms during metamorphosis a more extensive RT-PCR analysis using RNA from 5 replicate larvae from each stage of metamorphosis was performed. Both splice variants were found in all developmental stages, with the ratio between the forms essentially constant and the smaller isoform predominating (Fig. 3b). In contrast, Fig. 3a indicates that the ratio of the TR $\beta$ splice variant isoforms varies considerably between different adult tissues, with the larger form 
making a more significant contribution to total TR $\beta$ levels in brain, cardiac muscle, red muscle and white muscle.

\subsection{Structure of teleost TR $\beta$ genes}

Clearly there is some variability in the TR $\beta$ isoforms found in different fish species, and between fish and tetrapods. Teleost TR $\beta$ genes characterised to date contain a $27 \mathrm{bp}$ insert missing from the corresponding gene from tetrapods (as well as from TR $\alpha$ genes from both fish and tetrapods). However, in Atlantic salmon (Marchand et al., 2001) this insert is absent from some transcripts due to alternative splicing. Similarly the $27 \mathrm{bp}$ insert appears present in some but not all TR $\beta$ transcripts from zebrafish (Danio rerio) since two zebrafish TR $\beta$ cDNA sequences have been deposited in GenBank that either include or lack the insert sequence (accession numbers NM_131340 and AF302242). Two alternatively spliced forms of TR $\beta$ have also been found in Japanese flounder (Yamano and Inui, 1995) and Atlantic halibut (this study), but in contrast to Atlantic salmon and zebrafish, they both contain the $27 \mathrm{bp}$ fish-TR $\beta$ specific insert with the larger isoform having an additional insert of $60 \mathrm{bp}$ immediately prior to it.

In an attempt to determine the origin of the different TR $\beta$ splice variants, we analysed the sequence of Fugu Mayffold M001021, which includes the TR $\beta$ gene. Comparison of the genomic sequence of Fugu TR $\beta$ to the full length TR $\beta$ cDNA (Nowell et al., 2001) from sea bream (Sparus auratus) and the partial cDNA from Atlantic halibut using Spidey (http://www.ncbi.nlm.nih.gov/spidey/) indicated that the coding sequence of Fugu TR $\beta$ is split into 9 exons (not shown). Exon 6 encodes both the 27bp fish-specific insert and the 
larger splice variant (which includes the extra 60bp) present in both Atlantic halibut and Japanese flounder. This larger variant arises because the upstream intron has two potential 3' (acceptor) splice sites. When the more downstream site is used the resulting mRNA contains the $27 \mathrm{bp}$ fish specific insert. However, both the 27bp insert and the additional 60 nucleotides immediately upstream of it are included in transcripts generated by use of the more upstream splice site. The sequences of the alternatively spliced region of the Atlantic halibut TR $\beta$ s, and the proposed origin of the alternatively spliced variants, are shown in Fig. 3c and Fig. 3d. Although the gene structure shown in Fig. 3d is based on analysis of the Fugu genome, we have obtained strong evidence that this organisation is conserved in Atlantic halibut. PCR reactions were performed on Atlantic halibut genomic DNA with primers that recognise sequences in exon 7 and the $5^{\prime}$ region of exon 6 (GTATTTGCCATGGACGCTTG and CGAGGAAGCTATGCTCTCTAATG respectively). This led to the isolation and subsequent sequencing of a $448 \mathrm{bp}$ fragment that, as predicted, includes a contiguous sequence corresponding to the $27 \mathrm{bp}$ and $60 \mathrm{bp}$ TR $\beta$-specific inserts (i.e. the sequences designated exon $6 \mathrm{a}$ and exon $6 \mathrm{~b}$ in Fig. 3D), followed by a 325bp intron and a short region of exon 7 (data not shown).

\section{Discussion}

\subsection{The TR family in fish}

A confusing collection of TR sequences have been described in fish including some isoforms that represent the products of distinct genes and others that arise through 
alternative splicing. Two TR $\alpha$ genes have been described in Japanese flounder, conger eel and Atlantic salmon and searches of the genome sequence of Fugu rubripes indicate two TR $\alpha$ genes in this species also. However, only one $\operatorname{TR} \beta$ gene appears to be present in the Fugu genome and only one TR $\beta$ gene has been found in most teleost species, although multiple isoforms may be produced through alternative splicing. An exception is the conger eel which has at least two TR $\beta$ genes. In an attempt to determine relationships between the different receptor isoforms in teleosts, phylogenetic analyses were performed using teleost TR protein sequences (the regions corresponding to the amino acid sequences shown in Fig. 1). Unfortunately parsimony, maximum likelihood and distance methods, each gave trees with differing topologies and with branches often having very weak bootstrap support (not shown). However, all trees showed TR $\beta$ s forming a separate branch, with the two conger eel TR $\beta$ genes grouped together. It therefore seems most likely that, following the whole genome duplication believed to have occurred during teleost evolution (Jaillon et al., 2004), duplicated TR $\alpha$ genes were retained whereas one of the duplicated TR $\beta$ genes was lost, with a subsequent TR $\beta$ gene duplication occurring in the anguilliform lineage.

Alternative splicing of $\operatorname{TR} \beta$ transcripts is commonly seen in teleosts, with the TR $\beta$ genes of Atlantic salmon, zebrafish, Japanese flounder, Atlantic halibut and conger eel each producing two or more isoforms through alternative splicing. However, the alternative splicing products from the Atlantic salmon and zebrafish gene differ somewhat from those of the other species. Atlantic salmon and zebrafish produce alternatively spliced $\operatorname{TR} \beta$ transcripts that either lack or possess the $27 \mathrm{bp}$ teleost-specific insert. In contrast, all 
TR $\beta$ mRNAs in Japanese flounder, Atlantic halibut and conger eel possess the $27 \mathrm{bp}$ insert, but each of these species also produces an additional TR $\beta$ splice variant that includes an additional 60 nucleotides immediately upstream of the 27 nucleotide insert referred to above. Our analysis of the TR $\beta$ gene from Fugu shows the presence of a fishspecific TR $\beta$ exon and indicates that the splice variants in Atlantic halibut, Japanese flounder and Conger eel most likely arise due to the use of alternative 3 ' splice sites (Fig. 3). There is as yet no evidence as to whether there are functional differences between the $\operatorname{TR} \beta$ splice variants or between $\mathrm{TR} \alpha \mathrm{A}$ and $\mathrm{TR} \alpha \mathrm{B}$.

\subsection{Whole body TH levels in metamorphosing larvae}

The variations during Atlantic halibut ontogeny of $\mathrm{T}_{4}$ and $\mathrm{T}_{3}$ in the present study are similar, but not identical, to those found in a previous study of the ontogeny of the pituitary thyroid axis in the Atlantic halibut (Einarsdottir et al., 2006). In the present study, much lower variability in TH levels between individuals of the same stage was obtained and a significantly higher concentration of both $\mathrm{T}_{4}$ and $\mathrm{T}_{3}$ was detected at metamorphosis (stage 9). The reason for the difference between the two studies may be a consequence of the careful collection of individual samples instead of pools, use of a validated staging scheme (Sæle et al., 2004) and the introduction of a heat treatment step prior to RIA of samples. Although previous studies of THs during ontogeny of salmonids (de Jesus and Hirano, 1992; Tagawa and Hirano, 1987; Leatherland et al., 1989), striped bass (Morone saxatilis) and conger eel (Brown et al., 1987; Yamano et al., 1991b) have not reported problems of interassay variability of $\mathrm{T}_{3}$ in the same samples or between different samples, this was found to be a difficulty with the Atlantic halibut larval 
extracts. The use of a heat treatment is an indispensable step in sample preparation for the analysis of THs in human plasma samples (Neeley and Alexander, 1983) in order to overcome the "matrix" effect caused by complexity of biological samples (Selby, 1999). In the present study, after extensive validation sample heat treatment was introduced prior to assaying larval extracts.

$\mathrm{T}_{4}$ levels were low and showed relatively little variation up until metamorphosis (stage 9) and immediately after metamorphosis (stage 10) when it was significantly higher than all previous developmental stages. A dramatic increase in $\mathrm{T}_{3}$ occurred at metamorphic climax (Fig, 2). This is not surprising given that $\mathrm{T}_{3}$ is the more potent form of thyroid hormone and that thyroid hormone treatment is known to drive metamorphosis. These observations provide further confirmation of the importance of thyroid hormones in flatfish metamorphosis and are remarkably similar to observations in the amphibian Xenopus laevis in which both $\mathrm{T}_{4}$ and $\mathrm{T}_{3}$ are elevated during metamorphosis. However, the results contrast somewhat to those in Japanese flounder (De Jesus et al., 1991) in which $\mathrm{T}_{4}$ peaks but $\mathrm{T}_{3}$ does not during metamorphosis. It would be of interest to reassesses the concentration of THs previously reported in a number of teleosts after the introduction of a heat treatment step in sample preparation.

\subsection{Expression of TRs during metamorphosis of Atlantic halibut}

Using quantitative PCR, TR $\alpha \mathrm{B}$ was found to be expressed at similar levels throughout most stages of metamorphosis with a clear decline in expression in metamorphosed juveniles (stage 10). TR $\alpha \mathrm{A}$ appears to peak at stage 9 as does TR $\beta$, with the latter but 
not former peak being statistically significant. The TR $\beta$ measurements reflect the total amount of TR $\beta$ mRNA, i.e. both the TR $\beta A$ and TR $\beta B$ splice variants. RT-PCR analysis showed that the ratio of the small and large forms is essentially constant throughout metamorphosis, with the smaller (TR $\beta A$ ) form predominating.

The TR expression profiles we report for Atlantic halibut are similar, but not identical, to those described in two other flatfish, turbot (Scophtalmus maximus) and Japanese flounder (Marchand et al., 2004; Yamano and Miwa, 1998), with the changes in TR gene expression in all three flatfish species being markedly less dramatic than those that occur during amphibian metamorphosis (Yaoita and Brown, 1990). TR $\alpha$ B expression appears to contribute a greater proportion of total TR in Atlantic halibut than in Japanese flounder (no data on TR $\alpha \mathrm{B}$ is available from turbot), and, more significantly, in Atlantic halibut it is $\operatorname{TR} \beta$ that shows the most distinct peak during metamorphosis whereas in Japanese flounder and turbot it is $\mathrm{TR} \alpha \mathrm{A}$. In turbot, $\mathrm{TR} \beta$ expression has been reported as being low and relatively constant throughout metamorphosis, increasing thereafter. In Japanese flounder TR $\beta$ levels are elevated at metamorphic climax, but reach still higher level in post-climax individuals.

In summary, in the flatfish species analysed to date there is appreciable expression of TRs prior to metamorphosis with TR $\beta$ and/or TR $\alpha$ A peaking around metamorphic climax. TR $\alpha 2$ expression in Atlantic halibut and Japanese flounder is more constant although in both species there is a decline in transcript levels after the completion of metamorphosis. The expression profiles of TRs in flatfish are consistent with the model 
previously proposed for Xenopus laevis (Sachs et al., 2000) in which, prior to metamorphosis, TRs in the absence of ligand act as repressors of metamorphosisassociated genes. As THs accumulate the receptors become associated with ligand and activate rather than repress their target genes. The change in receptor expression detected during the present study may indicate that TR $\alpha A$ and $\operatorname{TR} \beta$ are themselves the products of TH-target genes thus explaining their increased expression during metamorphic climax. Consistent with this, studies in zebrafish suggest that both TR $\alpha$ A and TR $\beta$ are THinducible (Liu et al., 2000). Further investigation is needed to fully understand the roles of THs in flatfish metamorphosis, especially the question of how THs can evoke a response that leads to body asymmetry. Important goals for future investigation will be to determine the expression profiles of the deiodinase enzymes that regulate $\mathrm{TH}$ levels in peripheral tissues and to identify genes that are induced or repressed at metamorphosis by THs.

\section{Acknowledgements}

This work has been carried out within the project "Arrested development: The Molecular and Endocrine Basis of Flatfish Metamorphosis" (Q5RS-2002-01192) with financial support from the Commission of the European Communities. However, it does not necessarily reflect the Commission's views and in no way anticipates its future policy in this area. We thank Heiddis Smáradóttir (Fiskeldi Eyjafjarðar, IS-600 Akureyri, Iceland) for collecting and providing the Atlantic halibut samples, and Karin Pittman and Øystein Sæle (both from the Department of Biology, University of Bergen, Norway) for analysing 
samples to determine developmental stage. We are also grateful to Marco Campinho for preparing the RNA used in the study.

\section{References}

Brown, C.L., Sullivan, C.V., Bern, H.A., Dickhoff, W.W., 1987. Occurrence of thyroid hormones in early developmental stages of teleost fish. Am. Fish. Soc. Symp. 2, 144-150.

Brown, D.D., Cai, L., 2007. Amphibian metamorphosis. Dev. Biol. 306, 20-33.

Brown, D.D., 2005. The role of deiodinases in amphibian metamorphosis. Thyroid 15, $815-821$.

Buchholz, D.R., Paul, B.D., Fu, L., Shi. Y.B., 2006. Molecular and developmental analyses of thyroid hormone receptor function in Xenopus laevis, the African clawed frog. Gen. Comp. Endocrinol. 145, 1-19.

Buchholz, D.R., Tomita, A., Fu, L., Paul, B.D., Shi, Y-B., 2004. Transgenic analysis reveals that thyroid hormone receptor is sufficient to mediate the thyroid hormone signal in frog metamorphosis. Mol. Cell. Biol. 24, 9026-9037. 
Cai, L., Brown, D.D., 2004. Expression of type II iodothyronine deiodinase marks the time that a tissue responds to thyroid hormone-induced metamorphosis in Xenopus laevis. Dev. Biol. 266, 87-95.

Campinho, M.A., Silva, N., Sweeney, G.E., Power, D.M., 2007a. Molecular, cellular and histological changes in skin from a larval to an adult phenotype during bony fish metamorphosis. Cell Tissue Res. 327, 267-284.

Campinho, M.A., Silva, N., Nowell, M.A., Llewellyn, L., Sweeney, G.E., Power, D.M., 2007b. Troponin T isoform expression is modulated during Atlantic Halibut metamorphosis. BMC Dev Biol. 7:71.

Cheng, S.Y., 2005. Isoform-dependent actions of thyroid hormone nuclear receptors: lessons from knockin mutant mice. Steroids. 70, 450-454.

Davis, P.J., Davis, F.B., 1996. Nongenomic actions of thyroid hormone. Thyroid 6, 497504.

De Jesus, E.G., Hirano, T., Inui, Y., 1991. Changes in cortisol and thyroid hormone concentrations during early development and metamorphosis in the Japanese flounder, Paralichthys olivaceus. Gen. Comp. Endocrinol. 82, 369-376. 
De Jesus, E.G., Hirano, T., 1992. Changes in whole body concentrations of cortisol, thyroid hormones, and sex steroids during early development of the chum salmon, Oncorhynkus keta. Gen. Comp. Endocrinol. 85, 55-61.

De Jesus, E.G., Hirano, T., Inui, Y., 1993. Flounder metamorphosis - its regulation by various hormones. Fish. Physiol. Biochem. 11, 1-6.

Einarsdottir, I.E., Silva, N., Power, D.M., Smaradottir, H., Bjornsson, B.T., 2006. Thyroid and pituitary gland development from hatching through metamorphosis of a teleost flatfish, the Atlantic halibut. Anat. Embryol. 211, 47-60.

Flamant, F., Samurat, J., 2003. Thyroid hormone receptors: lessons from knockout and knock-in mutant mice. Trends Endocrinol Metab. 14, 85-90.

Forrest, D., Erway, L.C., Ng, L., Altschuler, R., and Curran, T. 1996a. Thyroid hormone receptor $\beta$ is essential for development of auditory function. Nat. Genet. 13, 354-357.

Forrest, D., Hanebuth, E., Smeyne, R.J., Everds, N., Stewart, C.L., Wehner, J.M., Curran T., 1996b. Recessive resistance to thyroid hormone in mice lacking thyroid hormone receptor beta: evidence for tissue-specific modulation of receptor function. EMBO J. 15, 3006-3015. 
Gudernatsch, J.F., 1912, Feeding experiments on tadpoles. I. Influence of specific organs given as food on growth and differentiation: a contribution to the knowledge of organs with internal secretion: Archives of Entwicklungsmech. Org. 35, 457-483.

Guissouma, H., Dupre, S.M., Becker, N., Jeannin. E., Seugnet. I., Desvergne, B., Demeneix, B.A., 2002. Feedback on hypothalamic TRH transcription is dependent on thyroid hormone receptor $\mathrm{N}$ terminus. Mol. Endocrinol. 16, 1652-1666.

Hiroi, Y., Kim, H.H., Ying, H., Furuya, F., Huang, Z., Simoncini, T., Noma, K., Ueki, K., Nguyen, N.H., Scanlan, T.S., Moskowitz, M.A., Cheng, S.Y., Liao, J.K., 2006. Rapid nongenomic actions of thyroid hormone. Proc. Natl. Acad. Sci. USA. 103, 14104-14109.

Jaillon, O., and 60 others 2004. Genome duplication in the teleost fish Tetraodon nigroviridis reveals the early vertebrate proto-karyotype. Nature 431, 946-957.

Jones, I., Rogers, S.A., Kille, P., Sweeney, G.E., 2002. Molecular cloning and expression of thyroid hormone receptor alpha during salmonid development. Gen. Comp. Endocrinol. 125, 226-235.

Kawakami,Y., Tanda, M., Adachi, S., Yamauchi, K., 2003a. Characterisation of thyroid hormone receptor alpha and beta in the metamorphosing Japanese conger eel, Conger myriaster. Gen. Comp. Endocrinol. 132, 321-332. 
Kawakami, Y., Tanda, M., Adachi, S., Yamauchi, K., 2003b. cDNA cloning of thyroid hormone receptor betas from the conger eel, Conger myriaster. Gen. Comp. Endocrinol. $131,232-240$.

Lazar, M. A., 1993. Thyroid hormone receptors: multiple forms, multiple possibilities. Endocr. Rev. 14, 184-193.

Leatherland, J.F., Lin, L., Down, N.E., Donaldson, E.M., 1989. Thyroid hormone content of eggs and early development stages of five Oncorhynchus species. Canad. J. Fish. Aquat. Sci. 46, 2140-2145.

Liu, Y-W., Lo, L-J., Chan, W-K., 2000. Temporal expression and $\mathrm{T}_{3}$ induction of thyroid hormone receptors [alpha]1 and [beta]1 during early embryonic and larval development in zebrafish, Danio rerio. Mol. Cell. Endocrinol. 159, 187-195.

Llewellyn, L., Nowell, M.A., Ramsurn, V.P., Wigham, T., Sweeney, G.E., Kristjansson, B., Halldorsson, O., (1999). Molecular cloning and developmental expression of the halibut thyroid hormone receptor- $\alpha$. J. Fish. Biol, 55a, 148-155.

Mai, W., Janier, M.F., Allioli, N., Quignodon, L., Chuzel, T., Flamant, F., Samarut, J., 2004. Thyroid hormone receptor alpha is a molecular switch of cardiac function between fetal and postnatal life. Proc. Natl. Acad. Sci. USA 101, 10332-10337. 
Marchand, O., Duffraisse, M., Triqueneaux, G., Safi, R., Laudet V., 2004. Molecular cloning and developmental expression patterns of thyroid hormone receptors and $\mathrm{T}_{3}$ target genes in the turbot (Scophtalmus maximus) during post-embryonic development. Gen. Comp. Endocrinol. 135, 345-357.

Marchand, O., Safi, R., Escriva, H., Van Rompaey, E., Prunet, P., Laudet,V., 2001. Molecular cloning and characterization of thyroid hormone receptors in teleost fish. J. Mol. Endocrinol. 26, 51-65.

Miwa, S., Inui, Y., 1991. Thyroid hormone stimulates the shift of erythrocyte populations during metamorphosis of the flounder. J. Exp. Zool. 259, 222-228.

Neeley, W.E., Alexander, N.M.,1983. Polyclonal 3,5,3'-triiodothyronine $\left(\mathrm{T}_{3}\right)$ antibodies in a euthyroid woman and their effect on radioimmunoassays for $\mathrm{T}_{3}$. J. Clin. Endocrinol. Metab. 57, 851-854.

Nowell, M.A., Power, D.M., Guerreiro, P.M., Llewellyn, L., Sweeney, G.E., 2001. Characterisation of a sea bream (Sparus aurata) thyroid hormone receptor- $\beta$ clone expressed during embryonic and larval development. Gen. Comp. Endocrinol. 123, 8089.

Oetting, A., Yen, P.M., 2007. New insights into thyroid hormone action. Best Pract Res Clin Endocrinol Metab. 21, 193-208. 
Sachs, L.M., Damjanovski, S., Jones, P.L., Li, Q., Amano, T., Ueda, S., Shi, Y.B., Ishizuya-Oka, A., 2000. Dual functions of thyroid hormone receptors during Xenopus development. Comp. Biochem. Physiol. B. 126, 199-211.

Sæle, O., Solbakken, J.S., Watanabe, K., Hamre, K., Power, D., Pittman, K., 2004. Staging of Atlantic halibut (Hippoglossus hippoglossus L.) from first feeding through metamorphosis, including cranial ossification independent of eye migration. Aquaculture $239,445-465$.

Schreiber, A.M., Das, B., Huang, H., Marsh-Armstrong, N., Brown, D. D., 2001. Diverse developmental programs of Xenopus laevis metamorphosis are inhibited by a dominant negative thyroid hormone receptor. Proc. Natl. Acad. Sci. USA. 98, 1073910744.

Selby, C., 1999. Interference in immunoassay. Ann. Clin. Biochem. 36, 704-721.

Solbakken, J., Norberg, B., Watanabe, K., Pittman, K., 1999. Thyroxine as a mediator of metamorphosis of Atlantic halibut (Hippoglossus hippoglossus L.). Environmental Biology of Fishes 56, 53-65. 
Tagawa, M., Hirano, T., 1987. Presence of thyroxine in eggs and changes in its content during early development of chum salmon, Oncorhynchus keta. Gen. Comp. Endocrinol. $68,129-135$.

Tata, J. R., 2006. Amphibian metamorphosis as a model for the developmental actions of thyroid hormone. Mol. Cell. Endocrinol. 246, 10-20.

Wakahara, M., Yamaguchi, M., 2001. Erythropioesis and conversion of RBCs and hemoglobins from larval to adult type during amphibian development. Zool. Sci. 18, 891-904.

Yamano, K., Miwa, S., Obinata, T., Inui, Y., 1991a. Thyroid hormone regulates developmental changes in muscle during flounder metamorphosis. Gen. Comp. Endocrinol. 81, 464-472.

Yamano, K., Tagawa, M., deJesus, E.G., Hirano, T., Miwa, S., Inui, Y., 1991b. Changes in whole body concentrations of thyroid hormones and cortisol in metamorphosing conger eel. J. Comp. Physiol. B. 161, 371-375.

Yamano, K., Araki, K., Sekikawa, K., Inui,Y., 1994. Cloning of thyroid hormone receptor genes expressed in metamorphosing flounder. Dev. Genet. 15, 378-382. 
Yamano, K., Inui, Y., 1995. cDNA cloning of thyroid hormone receptor beta for the Japanese flounder. Gen. Comp. Endocrinol. 99, 197-203.

Yamano, K., Miwa, S., 1998. Differential gene expression of thyroid hormone receptor $\alpha$ and $\beta$ in fish development. Gen. Comp. Endocrinol. 109, 75-85.

Yaoita, Y., Brown, D. D., 1990. A correlation of thyroid hormone receptor gene expression with amphibian metamorphosis. Genes Dev. 4, 1917-1924.

Yen, PM., Feng, X., Flamant, F., Chen, Y., Walker, R.L., Weiss, R.E., Chassande, O., Samarut, J., Refetoff, S., 2003. Effects of ligand and thyroid hormone receptor isoforms on hepatic gene expression profiles of thyroid hormone receptor knockout mice. EMBO Rep. 4, 581-587.

Zhang, J., Lazar, M. A., 2000. The mechanism of action of thyroid hormones. Ann. Rev. Physiol, 62, 439-466. 


\section{Figure Legends}

Fig. 1. Partial amino acid sequences of TR $\alpha \mathrm{A}, \mathrm{TR} \alpha \mathrm{B}$ and TR $\beta$ from Atlantic halibut. An asterisk (*) indicates a residue identical to that of TR $\alpha$ A. Hyphens (-) represent spaces inserted to maximise similarity.

Fig. 2. The top three panels show the relative expression of TR $\alpha A, T R \alpha B$ and TR $\beta$. The bottom two panels show changes in whole-animal $T_{4}$ and $T_{3}$ content $(\mathrm{pg} / \mathrm{mg})$ during halibut metamorphosis. Bars indicate standard error. In these analyses, stages with the same letter are not significantly different, those with different letters are significantly different $(\mathrm{p}<0.05)$.

Fig. 3. A) Analysis by RT-PCR of expression of splice variants of TR $\beta$ during larval development and in adult tissues. The $197 \mathrm{bp}$ and $257 \mathrm{bp}$ PCR products correspond to TR $\beta A$ and TR $\beta B$ respectively. B) Ratio of TR $\beta A$ :TR $\beta B$ splice variants in different developmental stages as determined by RT-PCR analysis of RNA from five individual larvae of each stage. Error bars indicate standard error. C) cDNA sequences of the alternatively spliced region of the halibut TR $\beta$ isoforms TR $\beta A$ and TR $\beta B$. The $27 \mathrm{bp}$ fish TR $\beta$-specific insert is shown in bold and the additional nucleotides present in TR $\beta B$ are underlined. D) Putative organisation of the Atlantic halibut TR $\beta$ gene, based on analysis of the TR $\beta$ sequence from Fugu rubripes. Rectangles represent exons with numbers corresponding to exon number in the Fugu gene. Exon 6 is alternatively spliced, with shading showing the $27 \mathrm{bp}$ fish-specific TR $\beta$ insert and the stippled box representing the additional 60 nucleotides present in TR $\beta B$. Dotted and dashed lines show the splicing patterns that generate TR $\beta A$ and TR $\beta B$ respectively. The arrows above exon 6 indicate alterative $3^{\prime}$ splice sites; the horizontal, double headed arrow indicates the region for which halibut genomic sequence has been obtained. 
Figure 1

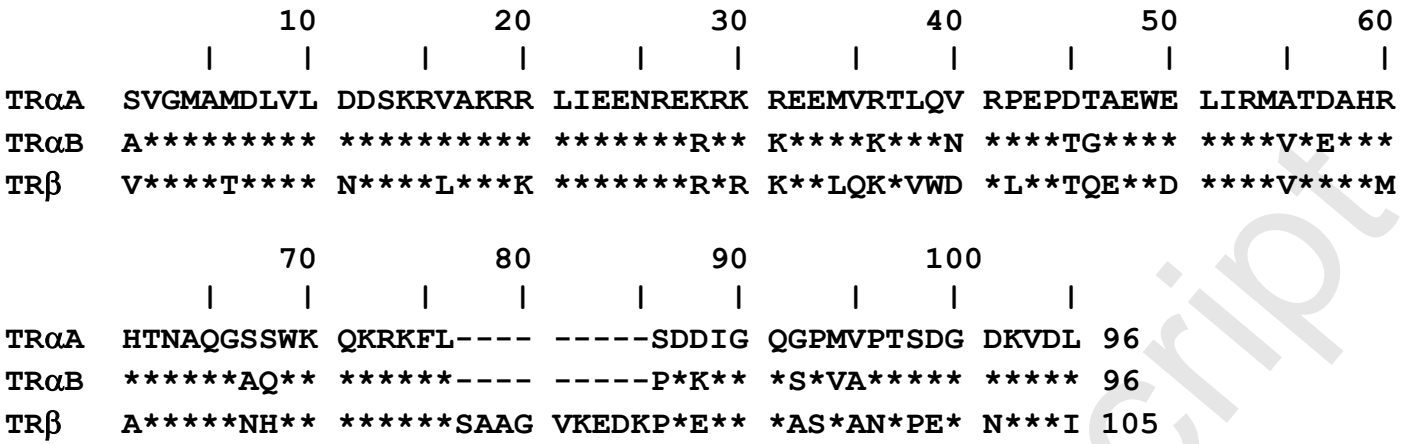


Figure 2

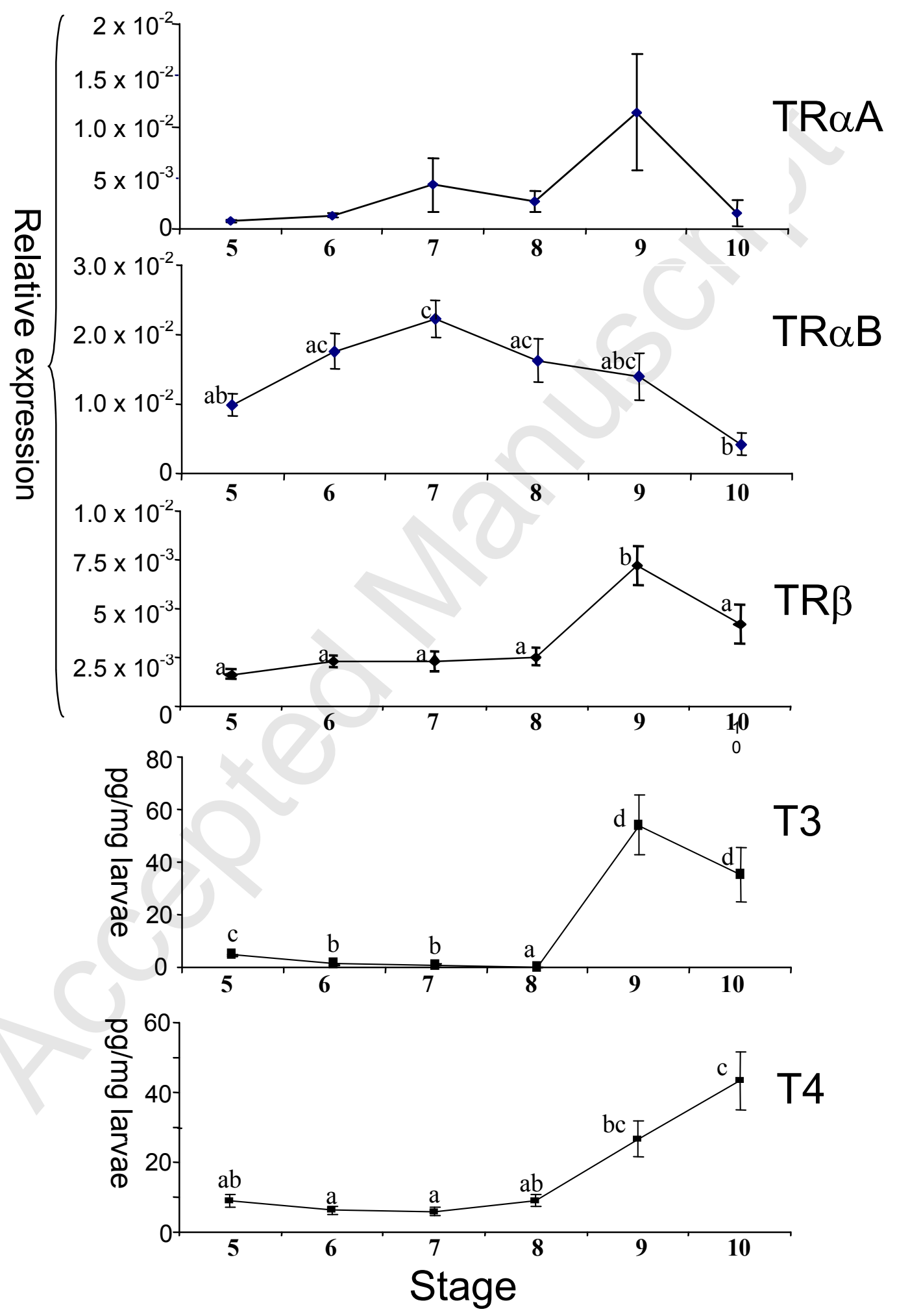


Figure 3

A
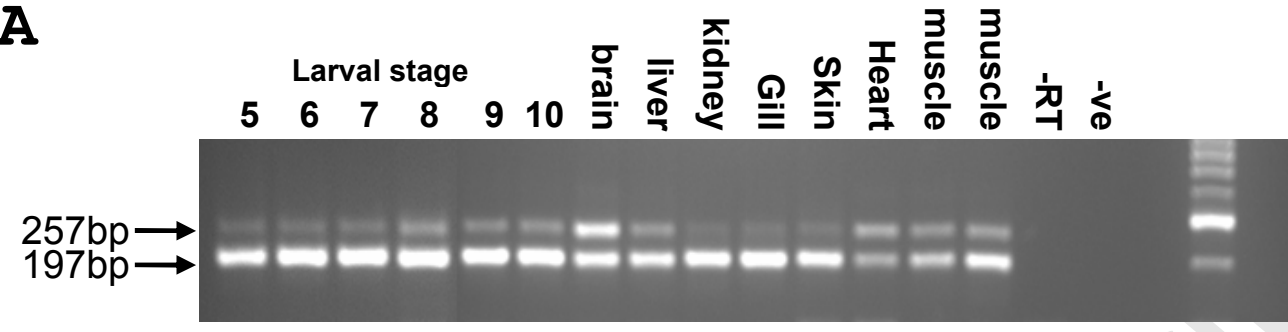

B

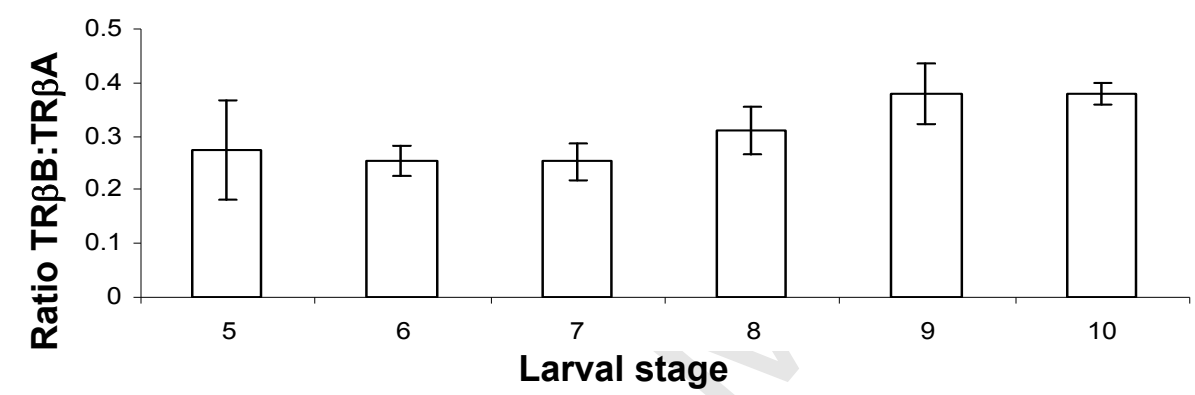

C

TRßA GGCCACGAATGCCCAGGGCAACCACTGGAAGCAGAAGCGGAAATTCCTG---------- 228 TRßB GGCCACGAATGCCCAGGGCAACCACTGGAAGCAGAAGCGGAAATTCCTGGTCGAGGAAGC 240

TRßB TATGCTTCTTAATGAATAACATGTAATTTATTCTATACTTCTGACCAGAGTGCAGCGg 300

TRßA GGTGAAGGAAGATAAGCCTGAGGAAATTGGTCAAGCGTCCATGGCAAATACACCTGAAGG 300 TRßB GGTGAAGGAAGATAAGCCTGAGGAAATGGTCAAGCGTCCATGGCAAATACACCTGAAGG 360

D

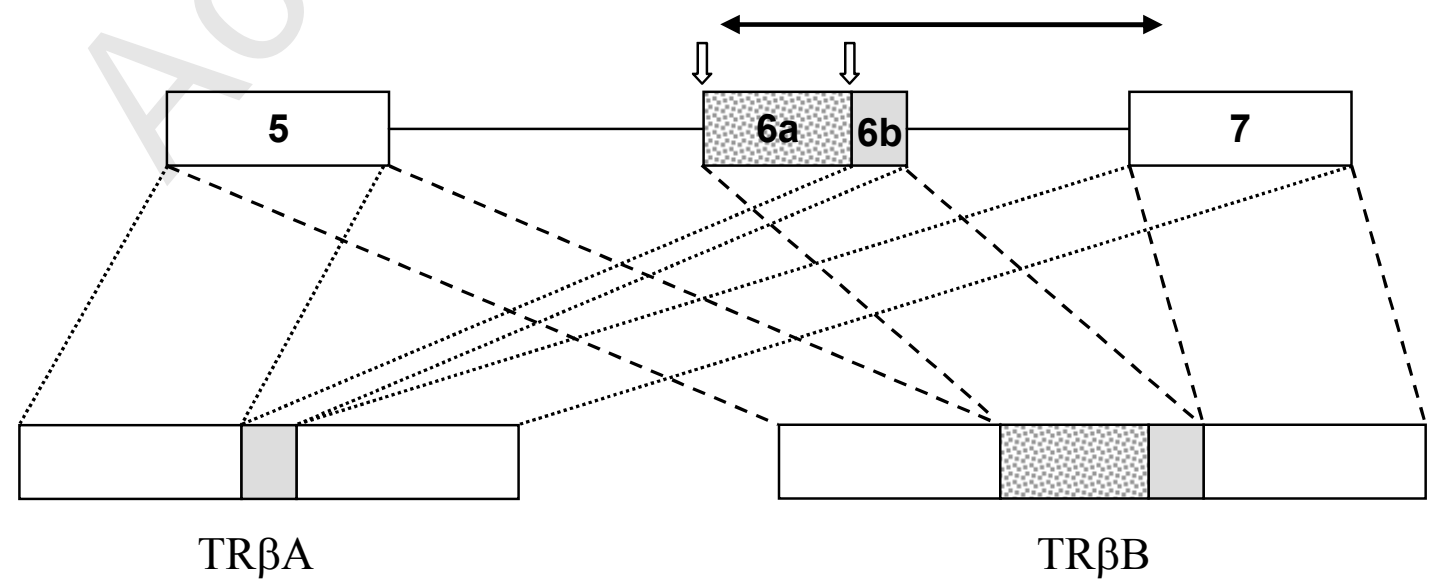

